\title{
The Impact of E-Banking on the Profitability of Banks: A Study of Pakistani Banks
}

\author{
Sana Haider Sumra (Corresponding Author) \\ Department of Management Sciences, The Islamia University of Bahawalpur, Pakistan \\ E-mail: sanasumras@yahoo.com \\ Mohammad Khurram Manzoor \\ Lahore School of Economics, Pakistan \\ E-mail: mkhurrammanzoor@gmail.com
}

Hassan H. Sumra

Management Sciences, COMSATS Institute of Information \& Technology, Pakistan

Tel: +92-331-755-7119 E-mail: Hassan.haider777@yahoo.com

\author{
Momina Abbas \\ MCB Bank Circle Office, 4-A Qasim Road, Dubai Chowk, Bahawalpur \\ Email: momina.abbas@mcb.com.pk
}

Received: May 25, 2011 Accepted: June 3, 2011 DOI: 10.5296/jpag.v1i1.692

\begin{abstract}
The proliferation and penetration of internet has opened new horizons and scenarios for the retail banking industry. The retail banks are now providing their products and services through the electronic medium; e-banking. E-banking is considered to have a substantial impact on banks' performance. The aim of this paper is to examine the impact of e-banking on the profitability of Pakistani banks, in particular.

This paper covers twelve banks across Pakistan. The study is qualitative in nature which examines different objectives which determine the performance of banks mainly in terms of profitability. It also discusses the effect of customers' literacy on provision of services from banks' perspective. It also discusses the basic motive of banks to adopt e-banking services.
\end{abstract}


The study is done through taking interviews from the managers of these banks.

The results show that e-banking has increased the profitability of banks; it has enabled the banks to meet their costs and earn profits even in the short span of time. The illiteracy of customers is not regarded as a major impediment in provision of their products and services. For banks, the main motive to adopt e-banking is to increase their clientage and to retain their customers. The profitability of banks has augmented in transitioning to e-banking medium.

Keywords: E-Banking, Public sector banks, Profitability, Information technology

\section{Introduction}

The revolution of information technology has influenced almost every facet of life, among them is the banking sector. The introduction of electronic banking has revolutionized and redefined the ways banks were operating. As technology is now considered as the main contribution for the organizations' success and as their core competencies. So the banks, be it domestic or foreign are investing more on providing on the customers with the new technologies through e banking. PC banking, mobile banking, ATM, electronic funds transfer, account to account transfer, paying bills online, online statements and credit cards etc. are the services provided by banks. Also the feature which is commonly unique to internet banking includes importing data into personal accounting software. Some online banking platforms support account aggregation to allow the customers to monitor all of their accounts in one place whether they are with their main bank or with other institutions. Banking through internet is considered as a complimentary delivery channel for the services rather than a substitute for the brick and mortar banking branches.

This research paper aims at examining the impact of electronic banking on the profits of Pakistani banks. E banking has increased the competition among the banks and both domestic and foreign banks are offering more and more modern ways of e-banking. The study investigates the services provided by the banks and their impact on their profitability in particular. It is significant due to the proliferation of the service sector and its importance in the economy. It also discusses about the services provided by the banks to its customers and also reveals the major rationales for the banks to use internet and other electronic mediums as the means to providing services to their customers. It is a distinguished one because it reveals the factors which lead to the success of the operations, giving more profits and the ability to manage risks of using electronic means and using the electronic services for the benefit of the bank and how they differentiate through these services in the market and the factors which lead to the increased profitability of banks, be it public or private.

The objectives of this research are to measuring and comparing of the effect of the introduction of new technologies through e banking on the profitability of domestic and foreign banks, how much the provision of these services effect the service quality of the banks and hence their efficiency, to assess the impact of changing from the traditional banking to the electronic banking on the banks and on the customers as well and also to examine the main motive or aim of the banks to provide these services to the customers and it also discusses the effect of customers' literacy on the provision of their services and hence 
their profits.

\section{Literature Review}

Electronic banking is referred to as using of the internet as delivery mode for the provision of services like opening a deposit account, electronic bill payments, and online transfers. These services can either be provided by the banks having physical offices and by creating a website and providing services through that or services can be provisioned through a virtual bank as well. Internet is used as a strategic and differentiating channel to offer high valued financial services complex products at same or improved quality at lower costs without physical boundaries and to cross sell products like credit cards and loans.

Apart from the poorly developed systems and structures, the developing countries may benefit from the technologies offered by today's world while building up their financial intermediation infrastructure. These technologies are provided through electronic banking.

Allen et al (2002) gave the definition of E-finance as "the provision of financial services and markets using electronic communication and computation”. The use of electronic communication in finance has the history further back than 1970s. Earlier, the payments between the banks resolved electronically over the telegraph. However, for payments let it be large or small are done effectively and efficiently over the electronic communication mechanisms. Boundaries between different financial institutions have been removed, due to electronic means for transactions the services and the product are now offered with more efficiency and quality.

Claessens et al (2001) presented the openings e-finance furnishes to the developing world. "E-finance can allow countries to establish a financial system without first building a fully functioning financial infrastructure. Because e-finance is much cheaper, since it lowers processing costs for providers and search and switching costs for consumers, providers can market financial services involving smaller transactions to lower-income borrowers, even in remote areas. To further this, government's main role will be to enhance the enabling environment."

The most significant policy issue is regarding providing an environment facilitating e-finance, providing regulatory and other reformatory frameworks for enforcing contracts, privacy, information communication, security, telecommunications and infrastructure for e-transactions.

E-finance can benefit financial sector development of emerging countries by lowering costs, increasing the breadth and quality and widening access to financial services. Birch and Young (1997) analyzed the consumer side for e-banking and the results showed that consumers basically seek for transactional efficiency, choice for core and non-core banking products and access to competitive prices and returns.

Onay et al (2008) in their research on Turkish banks concluded that e-banking has a positive impact on the profits of banks. According to their study, "Internet has changed the dimensions of competition in the retail banking sector. It has also provided opportunities for emerging 
countries to build up their financial intermediation infrastructure. Investment in e-banking is a gradual process. The internet banking variable has had a positive effect on the performance of the banking system in Turkey." Also, Siam (2006) examined the impact of e-banking on Jordanian banks and concluded that majority of the banks are providing services on internet through their websites and his findings show that the attention is more to achieving e-banking as satisfying and fulfilling customers' needs. He also concluded that there should be a well articulated strategy to achieve success and profits in the long run.

In their research, De Young et al (2007) analyzed the effect of e-banking on the performance of banks by studying US community banks markets and compared the performance of virtual click and mortar banks with brick and mortar banks. Their findings concluded that e-banking improved the profitability of banks hence increasing their revenues. Also, E-banking is largely driven by the factors of minimizing the operating costs and maximizing operating profit, suggests Simpson (2002). According to Centeno (2004), the e-banking adoption factors are divided into two categories:1). Factors relating to the infrastructure and accessing technology, 2). Factors that are related to retail banking factors. The prior factors include skills on the part of consumers in using internet and other related technologies, attitudes towards technologies, internet penetration rate, privacy and security concerns. Later involves factors like banking culture, e-banking culture, trust in banking institutions and internet banking push. However, lack of PC and internet penetrations serve as barriers for development of e-banking. Also, in their study conducted in Turkish retail banking sector Polatoglu and ekin (2001) concluded that e-banking decreases operational costs and it amplifies customers' satisfaction and retention.

The usage of e-banking induces many risk factors to firms' overall risk profile. The Basel committee has issued Risk Management Principles for Electronic Banking in July 2003, it has recognized the related risk factors and its purpose is to enhance and promote safety of services offered by e-banking while maintaining flexibility keeping in regard the changing technologies due to dynamic environment.

\section{Research Methodology}

The study is conducted assessing the qualitative factors in determining the impact of e-banking. It is descriptive and exploratory in nature. Survey is conducted by interviewing the managers of banks which include Habib Bank Limited, United Bank Limited, National Bank of Pakistan, Muslim Commercial Bank, Bank Al-Falah, Askari Bank Limited, Faysal Bank Limited, Saudi Pak Bank, Meezan Bank, Silk Bank, Khushali Bank and Bank Al-Habib Limited from three cities; Bahawalpur, Lahore and Islamabad. A common way to examining performance of banks' is through the level of banks' profitability.

Interviews were conducted from the managers of banks including Habib Bank Limited, United Bank Limited, National Bank of Pakistan, Muslim Commercial Bank, Bank Al-Falah, Askari Bank Limited, Faysal Bank Limited, Saudi Pak Bank, Meezan Bank, Silk Bank, Khushali Bank and Bank Al-Habib Limited. The electronic services provided by the banks' are ATM, Credit Cards, Phone banking, PC banking, SMS banking, Funds Deposit, Local Funds Transfer, Bill payment, Cheque payment, Balance enquiry, Statement of Account, 
Demand Draft, Pay Order, Remittance, Insurance and call Centers.

\section{Findings}

Managers affirmed that e-banking has changed the business environment. Manual banking has been reduced; the culture of keeping ledgers and recording transactions by hand has diminished by the advent of electronic banking. Now, banking has become real fast, customers get the services more quickly and reliably, the local and international transactions require a very less time as compared to before. It has also increased the competition and now all the banks tend to provide these services and facilities to the customers also, the environment and ambiance provided by the banks is a factor which complements their clientage, loyalty and banks' profits. At first, the customers had to follow a long and agonizing procedure even for account opening but now, owing to e-banking this procedure has become a "one window operation" where the authority is localized to the cashier which serves as convenience for customers. The funds can be transferred from account to account, bank to bank and even internationally in a very less period of time as compared to before which took days for the purpose. Banks are linked with each other within the country and also a few are linked with banks with other countries, this has increased the accessibility of the customers and also the number of customers for the banks. Visa cards have made it possible to make transactions globally. E-banking has opened new scenarios, increased service quality and more customers. Customers seek all the facilities under one roof and banks are devising more and more electronic banking techniques to cater their customers and for their retention. Call center facility has been provided by many banks in order to answer to their needs and problems. The relationships with the customers have enhanced due to these measures undertaken by banks for better customer services.

The main motive for e-banking identified by the all bank managers was their customers, to amplify their clientage, to increase customer satisfaction, retention and business expansion which would eventually gain them more profits. E-banking enables banks to achieve efficiency; it has reduced the requirements of manual maintaining as now the transactions and activities are recorded automatically on computers which in turn reduces human errors hence, increasing the accuracy, it saves time, labor costs as now less labor is required to do same amount of work, and it also has resulted in improvement in the services provided.

Another objective of this study is to assess the effect of customers' literacy. According to the bank managers, literacy is not a major hurdle for provision of e-banking services. Customers in the big cities are more educated and have more awareness and exposure than customers in small cities. They also added if the customers experience difficulties in using facilities provided to them due to their illiteracy, the bank employees help them and make them aware how to use the services by showing procedures by themselves and by educating them. So, literacy is not an issue in providing the usual electronic services. However, customers' literacy tends to be problem in utilizing the services of PC banking and mobile banking where customers in large cities have greater proportion of educated customers than those of small cities.

Lastly, the objective of the study was to examine the impact of e-banking on the profitability 
of banks. The managers confirmed e-banking as contributing to the profits of their businesses. They added that however, the banks have borne considerable costs for implementing e-banking; its infrastructure, for the training of their employees and creating the environment which would increase their service quality, image, brand value and goodwill. These implementation costs have been well covered by the banks in a few months time. The managers said that banks do not have to wait for years to cover up their costs rather, these are met in short run and even they start achieving profits.

Managers have shown a positive attitude towards e-banking; they concluded that e-banking is enhancing profitability and financial positions of banks and banks are striving hard to provide more and more services to their customers and to move towards advance and modern e-banking services also developing infrastructure. They revealed that up till 2013 the banks will completely adopt e-banking and it all dimensions.

\section{Conclusion and Discussion}

As now the scope is transferring to plastic money, the electronic banking is gaining more importance by the passing time. The electronic banking services provided by the banks include ATM, credit cards, funds transfer, cheque payment, funds deposit, balance enquiry, utility bills payment, statement of account, remittance, draft, pay order, phone banking, mobile banking, PC banking etc. the interviews from various bank managers have given rise to many findings about the impact of e banking on profitability, service quality and efficiency. The introduction of e banking has changed the banking environment. The manual banking was a lengthy and time consuming procedure, there was manual maintaining of the accounts and transactions for which the accuracy was damaged due to human errors, labour cost was considerable.

By the initiation of e banking, the efficiency of banks has been increased, the labour costs have decreased as now, less number of employees are required to deliver the services because of electronic means, the accuracy of transactions and maintenance has been also supplemented as computer has taken the place of humans hence, decreasing human errors, the procedures, processes and services are now fast and reliable which saves time, efforts and costs. The customers are more satisfied with the services, their accuracy and timeliness. This has in turn augmented the efficiency of banks; decreasing the costs and increasing profits.

The main motive for the banks to switch towards electronic means is to increase their clientage, to serve the customers with best of the services, to facilitate them and to boost customers' loyalty. Also, the business expansion was another motive for which the electronic medium for provision of services. Increment in the clientage, clients' satisfaction, loyalty and business expansion results in increased profits for the banks.

The transition from traditional to electronic means has not affected banks in the negative way. In fact, profits tend to augment in transition also because customers who now seek these online services get them increasing customers' satisfaction which contributes to the customer loyalty and hence profits. The banks have acquired the benefits in the short run and they meet their costs within a few years even a few months time. Customers seek all he facilities, fast 
banking and a good environment; this is generating more and more competition day by day which banks are meeting through electronic means and ambiance.

According to the turn out from the interviews, customer literacy is not considered as a hindrance in banks' objectives to seek customer generation, satisfaction and profitability. The banks tend to generate customer awareness if they are providing services to uneducated customers, the employees cater to the needs for questions and issues faced by customers, call center facilities are provided by many banks and also the employees in the banks which overcomes illiteracy to a larger extent and thence, customer literacy is not considered as a deterrent in achieving profits for the banks.

Banks are also earning from these services in a way of commission and annual deductions. The banks charge a certain amount or flat charges or a certain percentage on products and services like ATMs, funds transfer etc. In the end, interviews from the bank managers have confirmed that electronic banking has a considerable impact on the profitability of banks. If the eras of traditional banking are compared to the present e-banking eras, the results show that e-banking has contributed positively and proliferated the profits of banks. Banks are gradually transitioning from manual means to the electronic means rather than jumping to electronic banking means. Efficiency has risen as the costs have been reduced; costs of labour, provision of services, time saved, accuracy, reliability and quality of services has improved. However, the managers added that the transitional impact is seen more for the big cities as compared to small cities.

The financial statements of these banks have also been studied for the research and these statements have also shown that the profitability of banks has increased to a large extent by incorporating electronic means in provision of their products and services.

\section{Recommendations}

Bank managers have identified impediments on the way of transitioning to electronic banking is the flaw in infrastructure for mobile banking. The cellular service providing companies have not yet provided sufficient facilities and services for which the banks are not yet able to properly deliver mobile banking services to their customers. Also, customer illiteracy is somewhat coming on the way of advent of PC banking as infrastructure in the country for information technology is not satisfactory, people use other electronic banking services regularly but they are not much informed about how to get advantage from PC banking and mobile banking.

\section{References}

Banan, M. (2008). The viewpoint of bank's staff about internet banking. 3rd international conference on E-commerce with focus on developing countries. Isfahan.

Jen-Her Wu, T.-L. H. (2006). Core Capabilities for Exploiting Electronic Banking. Journal of Electronic Commerce Research , 111-122.

John Carlson, K. F. (2001). Internet Banking:Market Developments and Regulatory Issues. Society of Government Economists Conference 2000. Washington, DC. 
Pooja Malhotra, B. S. (2009). The Impact of Internet Banking on Bank Performance and Risk: The Indian Experience. Eurasian Journal of Business and Economics , 43-62.

Sabah Abdullah Al-Somali, R. G. (2007). Internet Banking Acceptance in the Context of Developing Countries: An Extension of the Technology Acceptance Model. Birmingham: Operations \&Information Management Group, Aston Business School, Birmingham B47ET, UK.

Siam, A. Z. (2006). Role of the Electronic Banking Services on the Profits of Jordanian Banks. American Journal of Applied Sciences , 1999-2004.

Zwass, V., "Electronic Commerce and Organizational Innovation: Aspects and Opportunities," International Journal of Electronic Commerce, Vol. 7, No. 3: 7-37, 2003.

Daniel, E.M. and H.M. Wilson, "The Role of Dynamic Capabilities in E-Business Transformation," European Journal of Information Systems, Vol. 12: 282-296, 2003.

Baddeley, M. "Using E-cash in the New Economy: An Economic Analysis of Micropayment System," Journal of Electronic Commerce Research, Vol. 5, No. 4: 239-253, 2004.

Cheung, M.T. and Z. Liao, "Challenges to Internet E-Banking," Communications of the ACM, Vol. 46, No.12: 248-250, 2003.

Mattilia, M., Karjaluoto, H., Pento, T. (2003). Internet banking adoption among mature customers: early majority or laggards. Journal of Services Marketing, Vol.17(5), 514-28.

Sathye,M.(1999).Adoption of Internet banking by Australian consumer: An empirical investigation. International Journal of Bank. Vol. 17 (7), 324-334 